\title{
Pollution Index and Ecological Risk of Heavy Metals in the Surface Soils of Amir-Abad Area in Birjand City, Iran
}

\author{
Mohammad Hossein Sayadi ${ }^{1, *} ;$ Mehri Shabani ${ }^{1}$; Najmeh Ahmadpour ${ }^{1}$ \\ ${ }^{1}$ Department of Environment, School of Natural Resources and Environment, University of Birjand, Birjand, IR Iran \\ ${ }^{*}$ Corresponding author: Mohammad Hossein Sayadi, Department of Environment, School of Natural Resources and Environment, University of Birjand, Birjand, IR Iran. Tel: +98- \\ 561225068, Fax: +98-5612254066, E-mail:Mh_sayadi@yahoo.com
}

Received: June 12, 2014; Revised: October 31, 2014; Accepted: November 19, 2014

\begin{abstract}
Background: In the present era, the concentration of heavy metals in the environment is increasing. Due to the deleterious effects of these metals on human health as well as their dangerous consequences on ecosystem, special attention should be paid to remove them from the environment.

Objectives: The purpose of this study was to assess the ecological risk of heavy metals including lead ( $\mathrm{Pb}$ ), cadmium (Cd), copper (Cu), zinc (Zn), chromium (Cr) in surface soils of an Amir-Abad Area in Birjand City, Iran.

Materials and Methods: Soil Samples were collected from a depth of 0-20 cm at 16 stations with different users. The samples were passed through a 2-mm sieve after air drying. To determine the concentration of heavy metals, the samples were extracted by acid chloride and nitric acid and total concentrations of toxic elements were read using the atomic absorption spectrophotometry. The pollution index and ecological risk assessments were calculated for each element.

Results: The results showed that the ecological risk of surface soil for the users of the road-residential was high (1370.72) and notable (505.04), and the agricultural land use and livestock had the moderate ecological risk and dairy farm had low ecological risk. When the results of this study were compared to world standards, it was suggested that the areas with the road-residential areas were considered to be dangerous to health; this was directly related to developments of technology and pollution.

Conclusions: It can be concluded that residential-road land uses show the considerable pollution index and ecological risk.
\end{abstract}

Keywords:Risk; Heavy Metals; Soil Pollution

\section{Background}

An ecological risk assessment is the process to evaluate the likeliness of an environment to be impacted as a result of exposure to one or more environmental stressors. It is a flexible process, not only to organize and analyze data, information, assumptions, and uncertainties but also evaluate the likelihood of adverse ecological effects (1). However, the heavy metals are included as earth's crust forming components and also are naturally present all around the ecosystem. Their concentration can considerably increase via human activities (2). Nevertheless, many researchers have studied the adverse effects of heavy metals on various ecosystems in the past two decades.

Different human activities can contaminate urban soils. As an example, the transportation of goods and passengers (3), industries, factories and mining (4), agriculture (5), livestock(6), dust(7), municipal waste (8) can be specified.

Innumerable studies have been carried out worldwide related to the soil pollution importance and its negative impact on population health and the environment, such as Ireland (9), Italy (10), Spain (11), Zimbabwe (12), Austra- lia (13), China (14) and also in some Iranian cities like Tehran (15), Isfahan (16), Hamadan (17) and Birjand (6).

Exposure to dust containing heavy metals leads to varied issues, including physical and mental retardation, decreased intelligence quotient, reduced concentration, headaches, cancer, increased blood pressure, renal and liver problems related to the nervous system, general weakness, and dysfunction of internal organs or aggravates via other diseases, and in some cases leads to death (18).

The study area was located on the west side of Birjand, 5 $\mathrm{km}$ off Birjand-Kerman road in South Khorasan Province. The potential sources of pollutants in this area were from agriculture and animal husbandry activities, urban activities, the presence of small shops and casual works and also passing one of the main roads of province along this residential area. There is also an industrial estate that can be considered as one of the essential human pollutant sources in environment (17).

\section{Objectives}

The purpose of this study was to assess the pollution 
index and ecological risk of heavy metals including lead $(\mathrm{Pb})$, cadmium $(\mathrm{Cd})$, copper $(\mathrm{Cu})$, zinc $(\mathrm{Zn})$ and chromium $(\mathrm{Cr})$ in surface soils of the Amir-Abad Area, Birjand City, Iran.

\section{Materials and Methods}

\subsection{Sampling}

As the Figure 1 shows, the grid map is used to select the samples in the study area. Five sampling points at each sampling station (fourat the corners and one at the center of the grid) were collected.

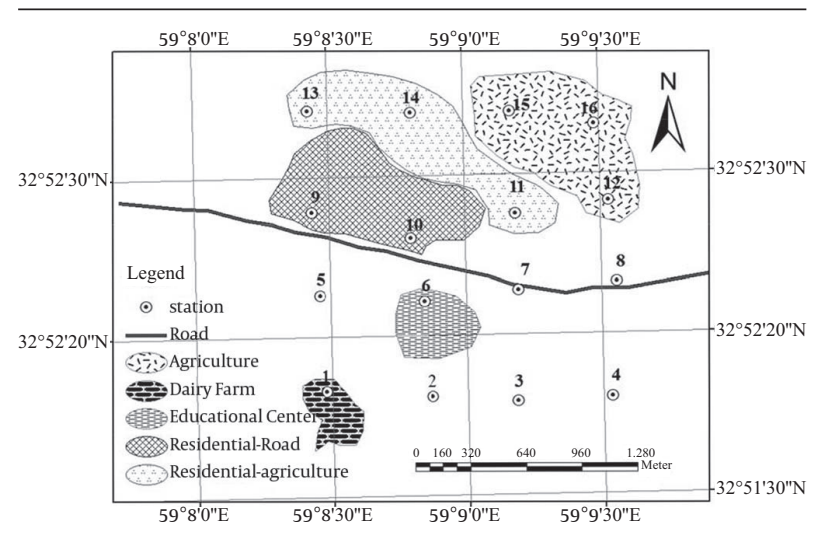

Figure 1. Mapof the Study Area With Sampling Stations

The samples were collected at 16 stations with different land uses between 0 and $20 \mathrm{~cm}$ soil depths, at each station, 5 samples with 3 replications were collected using the plastic spatula after removing the debris, rock pieces and physical contaminants.

A composite sample of $1.5 \mathrm{~kg}$ weight was prepared after mixing the 5 samples obtained from each station. Geographical locations of points were determined by global positioning systems. The samples were passed through a 2-mm sieve after air drying and to determine the concentration of heavy metals, the samples were extracted by acid chloride and nitric acid and total concentrations of toxic elements were read using the atomic absorption spectrophotometry (18).

\subsection{Calculation of Ecological Risk}

The ecological risks of heavy metals were calculated using the following equations (19).
Equation 1.
$\mathrm{PI}=\mathrm{Cs} / \mathrm{Bn}$

Equation 3. $\mathrm{RI}=\sum_{i=1}^{m} \mathrm{Er}$

Where"Cs" is the concentration of study metals, "Bn"is natural background value. "PI"is contamination index, "Er" is the indicator of each element's ecological risk and $\mathrm{RI}$ is the determinative of the total ecological risk.

The toxic response factor for a given compoundisshown by "Tr", "Er" is the potential risk index for given substance and "RI" is the potential ecological risk index for each area.

The results were analyzed after calculating the ecological risk for each element and the total ecological risk was evaluated. The following ranges of "RI" values were considered in the present study; low ecological risk RI $<150$, moderate ecological risk $150 \leq \mathrm{RI}<300$, high ecological risk $300 \leq \mathrm{RI}<600$ and considerable ecological risk RI $>600$ (19).

To calculate the background values in different studies, these values were chosen from previous researches (15), and to assess the amount of ecological risk, the "RI" and "Er" values were calculated using the equation2.

\section{Results}

The toxic metals via human activities can lead to soil pollution. These heavy metals are one of the most important pollutants that can cause serious problems to human health, plants and other organisms by entering the food chains (4). Table 1 depicts the comparison between the average concentration of the elements in the study area and the average concentration in the earth's crust. The results showed that the concentration of all elements except $\mathrm{Cr}$ were higher than the average of background values.

Equation 1 was used to assess the ecological risk of soil pollution via pollution index. Contamination levels were classified into six categories based on the pollution severity.

The results in Table 3 showed that most of the samples indicated low to moderate pollution. However, some users, especially residential-road areas demonstrated very high pollution.

Table 1. Average Concentrations of Heavy Metals in This Study and Earth Crust Level ${ }^{a}$

\begin{tabular}{lccccc}
\hline & Zn, mg/kg & Cr, mg/kg & Pb, mg/kg & Cd, mg/kg & Cu, mg/kg \\
\hline Surface soil in present study & $94.09 \pm 38.6$ & $63.79 \pm 11.5$ & $46.59 \pm 12.4$ & $1.53 \pm 0.7$ \\
Earth's crust(15) & 75 & 100 & 14 & 0.2 & $50.15 \pm 11.4$ \\
\hline
\end{tabular}

\footnotetext{
a Abbreviations: Zn, zink; Cr, chromium; Pb, lead; Cd, cadmium; $\mathrm{Cu}$, cupper.
} 
Sayadi MH et al.

\begin{tabular}{lc}
\hline Table 2. Classification of Pollution Index & Amounts \\
\hline Pollution Levels & 0 \\
\hline Unpolluted & 1 \\
\hline Unpolluted- moderate & 2 \\
Moderate pollution & 3 \\
\hline Moderate-high pollution & 4 \\
\hline High pollution & 5 \\
\hline High-very high pollution & 6 \\
\hline Very high pollution & 5 \\
\hline
\end{tabular}

\begin{tabular}{|c|c|c|c|c|c|c|c|c|}
\hline \multirow[t]{2}{*}{ Station Number } & \multirow[t]{2}{*}{ Land use } & \multicolumn{2}{|c|}{ Coordinates } & \multirow[t]{2}{*}{ Cd } & \multirow[t]{2}{*}{$\mathrm{Cr}$} & \multirow[t]{2}{*}{ Zn } & \multirow[t]{2}{*}{$\mathrm{Cu}$} & \multirow[t]{2}{*}{$\mathbf{P b}$} \\
\hline & & $\mathbf{N}$ & $\mathbf{E}$ & & & & & \\
\hline 1 & Dairy farm & 32.860 & 59.141 & 6.5 & 0.8 & 4.6 & 3.3 & 1.4 \\
\hline 2 & Natural land & 35.861 & 59.143 & 0.3 & 0.2 & 0.4 & 0.3 & 1 \\
\hline 3 & Natural land & 32.859 & 59.153 & 3 & 0.2 & 0.3 & 0.2 & 0.9 \\
\hline 4 & Natural land & 32.855 & 59.158 & 4.1 & 0.2 & 0.3 & 0.2 & 1.1 \\
\hline 5 & Natural land & 32.865 & 59.142 & 1.8 & 0.3 & 0.2 & 0.4 & 1.2 \\
\hline 6 & Educational center & 32.866 & 59.143 & 8.5 & 0.6 & 0.8 & 0.4 & 2 \\
\hline 7 & Road & 32.867 & 59.143 & 3.5 & 0.2 & 1.7 & 0.8 & 4.5 \\
\hline 8 & Road & 32.862 & 59.158 & 2.2 & 0.7 & 1.2 & 0.8 & 4.7 \\
\hline 9 & Residential- road & 32.869 & 59.145 & 14.6 & 1.9 & 1.6 & 4.5 & 7.9 \\
\hline 10 & Residential-road & 32.865 & 59.143 & 42.9 & 1.9 & 1.6 & 4.1 & 11.9 \\
\hline 11 & Residential-agriculture & 32.65 & 59.151 & 8 & 0.6 & 1.5 & 1 & 3.2 \\
\hline 12 & Agriculture & 32.868 & 59.158 & 2.3 & 0.6 & 1.1 & 0.6 & 4.2 \\
\hline 13 & Residential-agriculture & 32.878 & 59.138 & 5.1 & 0.4 & 1.4 & 0.7 & 3.6 \\
\hline 14 & Residential-agriculture & 32.879 & 59.142 & 4.7 & 0.4 & 1.7 & 0.9 & 2.4 \\
\hline 15 & Agriculture & 32.880 & 59.152 & 7.3 & 0.9 & 0.9 & 0.5 & 1.6 \\
\hline 16 & Agriculture & 32.881 & 59.155 & 7.6 & 0.3 & 0.7 & 0.5 & 1.8 \\
\hline
\end{tabular}

a Abbreviations: N, North; E, East.

$\mathrm{b}$ There is no unit, they are just number.

\section{Discussion}

The results of varied concentrations and their respective ecological risks are shown in Table 4. The average lead concentration was $59.46 \mathrm{mg} / \mathrm{kg}$, which was higher than its average in the earth's crust. The concentration of $\mathrm{Pb}$ was higher than the earth's crust in all the stations except stations 2 and 3 (Tables 1 and 2). Generally, lead is released from smelting, motor-vehicle exhaust fumes and corrosions of lead pipe work (20).

The average copper concentration was $60.15 \mathrm{mg} / \mathrm{kg}$, which was higher than its relative concentration in the earth's crust. However, this was true only for the station 2 and 10 (Tables 1 and 4). Both these stations caused the total concentration of this element to overpass than its average in the earth's crust. Cupper is extensively utilized in electrical cables, cooking appliances, pipes, chemical factories, metal melting furnaces, pigments and fertilizers (21). Although it is one of the essential elements for humans, but its overdoses could lead to neurological complications, hypertension, liver and kidney dysfunctions and even death (22).

The average Cd concentration was $1.53 \mathrm{mg} / \mathrm{kg}$, which was higher than the earth's crust. Except the second station, the concentration of Cd in other stations was higher than the earth's crust (Tables 1 and 4). Cadmium occurrence in the environment is from both natural and anthropogenic sources. Environmental levels are greatly enhanced by the existing industrial operations as Cd is commonly used as a pigment in paint, plastics, ceramics and glass manufacturing companies. Cadmium is highly toxic, producing symptoms such as nausea, vomiting, respiratory difficulties, cramps and loss of consciousness at high doses. Chronic exposure to this metal can lead to anemia, anosmia (loss of sense of smell), cardiovascular diseases, renal problems and hypertension (17). 
Sayadi MH et al.

\begin{tabular}{|c|c|c|c|c|c|c|c|c|c|c|c|c|}
\hline \multirow[t]{2}{*}{ Station } & \multicolumn{2}{|l|}{$\mathbf{P b}$} & \multicolumn{2}{|l|}{$\mathrm{Cu}$} & \multicolumn{2}{|l|}{ Zn } & \multicolumn{2}{|l|}{$\mathrm{Cr}$} & \multicolumn{2}{|l|}{ Cd } & \multirow[b]{2}{*}{ RIa } & \multirow[b]{2}{*}{$\begin{array}{c}\text { Ecological } \\
\text { Risk }\end{array}$} \\
\hline & $\begin{array}{l}\text { Concentra- } \\
\text { tion, mg/kg }\end{array}$ & Era & $\begin{array}{l}\text { concentra- } \\
\text { tion, } \mathrm{mg} / \mathrm{kg}\end{array}$ & Er & $\begin{array}{l}\text { Concentra- } \\
\text { tion, mg/kg }\end{array}$ & Er & $\begin{array}{l}\text { Concentra- } \\
\text { tion, mg/kg }\end{array}$ & Er & $\begin{array}{l}\text { Concentra- } \\
\text { tion, mg/kg }\end{array}$ & Er & & \\
\hline 1 & $19.4 \pm 4.2$ & 6.9 & $165.1 \pm 74.7$ & 16.5 & $346.5 \pm 201.3$ & 4.6 & $81.7 \pm 24.8$ & 1.6 & $1.3 \pm 0.4$ & 195 & 225 & moderate \\
\hline 2 & $13.9 \pm 6.3$ & 4.9 & $17.1 \pm 5.5$ & 1.7 & $33 \pm 11.8$ & 0.4 & $15.42 \pm 8.6$ & 0.3 & $0.05 \pm 0.01$ & 7.5 & 15 & low \\
\hline 3 & $12.2 \pm 2.5$ & 4.3 & $11.4 \pm 3.8$ & 1.2 & $24.8 \pm 15.3$ & 0.3 & $20.11 \pm 6.4$ & 0.4 & $0.6 \pm 0.01$ & 90 & 96 & low \\
\hline 4 & $15.4 \pm 4.3$ & 5.5 & $11.7 \pm 4.6$ & 1.1 & $21.2 \pm 7.6$ & 0.28 & $22.63 \pm 12.1$ & 0.5 & $0.82 \pm 0.03$ & 123 & 130 & low \\
\hline 5 & $17.3 \pm 8.1$ & 6.2 & $20.6 \pm 9.7$ & 2.1 & $18.2 \pm 4.6$ & 0.24 & $34.25 \pm 17.9$ & 0.7 & $0.36 \pm 0.1$ & 54 & 63 & low \\
\hline 6 & $28.2 \pm 13.4$ & 10 & $19.3 \pm 8.3$ & 1.9 & $56.7 \pm 27.3$ & 0.75 & $95.7 \pm 56.3$ & 1.2 & $1.7 \pm 0.7$ & 255 & 287 & moderate \\
\hline 7 & $62.8 \pm 29.6$ & 22.4 & $41.6 \pm 21.4$ & 4.1 & $125.2 \pm 49.6$ & 1.67 & $23.14 \pm 16.1$ & 0.5 & $0.69 \pm 0.2$ & 103 & 132 & low \\
\hline 8 & $56.1 \pm 18.4$ & 23.2 & $37.5 \pm 16.2$ & 3.7 & $93 \pm 31.9$ & 1.24 & $67.45 \pm 31$ & 1.3 & $0.44 \pm 0.2$ & 66 & 96 & low \\
\hline 9 & $109.9 \pm 37.5$ & 39.2 & $226.7 \pm 84.8$ & 22.5 & $118 \pm 74.1$ & 1.57 & $186.34 \pm 69.5$ & 3.7 & $2.92 \pm 1.1$ & 438 & 505 & high \\
\hline 10 & $166.6 \pm 79.3$ & 59.5 & $202.6 \pm 96.1$ & 20.2 & $122.6 \pm 32.9$ & 1.63 & $192.03 \pm 80.4$ & 3.8 & $8.57 \pm 3.6$ & 1285 & 1370 & considerable \\
\hline 11 & $45.4 \pm 23.7$ & 16.2 & $48 \pm 12.4$ & 4.8 & $113 \pm 65.3$ & 1.52 & $64.67 \pm 41.4$ & 1.3 & $1.59 \pm 0.8$ & 238 & 262 & moderate \\
\hline 12 & $58.2 \pm 25.1$ & 20.8 & $30.3 \pm 16.7$ & 3 & $80.1 \pm 56.2$ & 1.07 & $56.8 \pm 11.4$ & 1.2 & $0.46 \pm 0.1$ & 69 & 95 & low \\
\hline 13 & $49.7 \pm 18.6$ & 17.2 & $36.3 \pm 29.1$ & 3.6 & $105.4 \pm 83.8$ & 1.41 & $36.60 \pm 9.2$ & 0.7 & $1.01 \pm 0.3$ & 151 & 175 & moderate \\
\hline 14 & $33.4 \pm 16.8$ & 11.9 & $42.5 \pm 19.4$ & 4.4 & $127 \pm 42.2$ & 1.69 & $36.92 \pm 18.5$ & 0.7 & $0.93 \pm 0.3$ & 139 & 158 & moderate \\
\hline 15 & $22.2 \pm 11.1$ & 7.9 & $24.5 \pm 14$ & 2.4 & $68.5 \pm 33.3$ & 0.91 & $88.73 \pm 36.2$ & 1.8 & $1.46 \pm 0.9$ & 219 & 232 & moderate \\
\hline 16 & $25.5 \pm 13.2$ & 9.1 & $27.2 \pm 12.1$ & 2.7 & $52.2 \pm 12.1$ & 0.69 & $34.40 \pm 17.7$ & 0.7 & $1.51 \pm 0.8$ & 226 & 240 & moderate \\
\hline P Value & 0.001 & & 0.001 & & 0.001 & & 0.001 & & 0.001 & & & \\
\hline
\end{tabular}

a Abbreviations: Er, Ecological risk; RI, Determinative of the total ecological risk.

$\mathrm{b}$ There is no unit for them they are just number.

The average zinc concentration was 94.09, which was higher than the average concentration of the earth's crust, but it was lower in station 2 to 6,15 and 16 (Tables 1 and 4). This element is essential for growth of humans, animals and plants and is potentially dangerous for biosphere if present in high concentrations. It is often found in limestone. The main sources of pollution are industries and the use of liquid manure, composted materials and agrochemicals, such as fertilizers and pesticides in agriculture (23). Anemia, muscle pain, stroke, blood diseases and even death can be caused by zinc overdoses (17).

The average chromium concentration was $79.63 \mathrm{mg} /$ $\mathrm{kg}$, which was lower than the average of the earth's crust, but at stations 9 and 10 it was higher than the average of the Earth's crust (Tables 1 and 4). The major sources of chromium are textile factories, tanneries, pharmaceuticals and metals. Pigments containing oil compounds and greases also contain some amount of chromium (4). Chromium is considered as an essential trace element for the maintenance of an effective glucose, lipid and protein metabolism. High doses of chromium cause liver and kidney damage and chromate dust, which is carcinogenic (24).

Table 4 shows the result of ecological risk of heavy metals in surface soils of different land uses. The ecological risk of agriculture and livestock land use was moderate and as indicated by the ecological risks of each element (Er), cadmium is responsible for the pollution. The eco- logical risk of road and dairy farm land uses were low and road- residential land uses (station 9 and 10) demonstrated high and considerable ecological risk where Cd > $\mathrm{Pb}>\mathrm{Cu}>\mathrm{Cr}>\mathrm{Zn}$ were sequentially the most responsible elements. In the study of heavy metals $(\mathrm{Cu}, \mathrm{Cr}, \mathrm{Pb}, \mathrm{Ni}, \mathrm{Cd}$, $\mathrm{Zn}, \mathrm{Fe}, \mathrm{Mn}$ and $\mathrm{Li}$ ) for the determination of the ecological risks in Tehran city also demonstrated the high ecological risk at all samples (25).

The calculated potential ecological risk index at the Golestan Province, Iran, indicated that approximately $68 \%$ and $5 \%$ of the studied samples had medium and high pollution levels, respectively, whereas a moderate and high potential ecological risk covered about $90 \%$ of this province (26).

Population growth and modernization increase the contamination of soils and environment; therefore, it is essential to refine the soil and continually monitor the heavy metals. The average concentrations of $\mathrm{Pb}, \mathrm{Cu}, \mathrm{Zn}$ and Cd in surface soils of the study area were higher than their concentrations in the earth's crust indicating the presence of heavy metals in anthropogenic soils. The pollution index revealed that most of the samples were in moderate or not polluted areas, but was very high with considerable ecological risk in residential-road land uses.

\section{Acknowledgements}

This study, which was a research project conducted in 2013, was funded by the Research Council of the Univer- 
sity of Birjand. Authors would like to appreciate the authorities of the Research Council and Faculty of Natural Resources and Environment, University of Birjand, due to their sincere cooperation.

\section{References}

1. EPA.. Guidelines for Ecological Risk Assessment. 1998;63(93):26846-924.

2. Szefer P, Ali AA, Ba-Haroon AA, Rajeh AA, Geldon J, Nabrzyski M. Distribution and relationships of selected trace metals in molluscs and associated sediments from the Gulf of Aden, Yemen. ENV POLLUT,. 1999;106(3):299-314.

3. Thambiran T, Roseanne D. Air pollution and climate change cobenefit opportunities in the road transportation sector in Durban, South Africa. ATMOS ENV. 2011;45(16):2683-9.

4. Sayadi MH, Sayyed MRG, Shabani N. Quantification of heavy metal pollutants in the surface soils of Chitgar industrial area Tehran, Iran with spatial references to their spatial pattern. POLLUT RES. 2009;28:345-51.

5. Micó C, Recatalá L, Peris M, Sánchez J. Assessing heavy metal sources in agricultural soils of an European Mediterranean area by multivariate analysis. Chemosphere. 2006;65(5):863-72.

6. Sayadi MH, Rezaei MR. Impact of land use on the distribution of toxic metals in surface soils in Birjand city, Iran. PROC INT ACAD ECOL ENV SCI. 2014;4(1):18-29.

7. Lin C, Chen S, Huang K, Hwang W, Chang-Chien G, Lin W. Characteristics of Metals in Nano/Ultrafine/Fine/Coarse Particles Collected Beside a Heavily Trafficked Road. ENV SCI TECH. 2005;39(21):8113-22.

8. Sayyed G, Sayadi MH. Variations in the heavy metal accumulations within the surface soils from the Chitgar industrial area of Tehran. PROC INT ACAD ECOL ENV SCI. 2011;1(1):36-46.

9. Dao L, Morrison L, Zhang $\mathrm{H}$, Zhang $\mathrm{C}$. Influences of traffic on $\mathrm{Pb}$ $\mathrm{Cu}$ and $\mathrm{Zn}$ concentrations in roadside soils of an urban park in Dublin, Ireland. ENV GEOCHEM HEALTH. 2014;36(3):333-43.

10. Manta DS, Angelone M, Bellanca A, Neri R, Sprovieri M. Heavy metals in urban soils: a case study from the city of Palermo (Sicily), Italy. SCI TOTAL ENV. 2002;300(1-3):229-43.

11. Rodríguez JA, Nanos N, Grau JM, Gil L, López-Arias M. Multiscale analysis of heavy metal contents in Spanish agricultural topsoils. Chemosphere. 2008;70(6):1085-96.
12. Mapanda F, Mangwayana EN, Nyamangara J, Giller KE. The effect of long-term irrigation using wastewater on heavy metal contents of soils under vegetables in Harare, Zimbabwe. AGR ECOSYST ENV. 2005;107(2-3):151-65.

13. Tiller KG. Urban soil contamination in Australia. SOIL RES. 1992;30(6):937-57.

14. Wu S, Zhou S, Li X. Determining the anthropogenic contribution of heavy metal accumulations around a typical industrial town: Xushe, China.J Geochem Explor. 2011;110(2):92-7.

15. Sayadi MH, Sayyed MRG. Comparative assessment of baseline concentration of the heavy metals in the soils of Tehran (Iran) with the comprisable reference data. ENV Earth Sci. 2011;63(6):1179-88.

16. Amini M, Afyuni M, Khademi H, Abbaspour KC, Schulin R. Mapping risk of cadmium and lead contamination to human health in soils of Central Iran. Sci Total ENV. 2005;347(1-3):64-77.

17. Sayadi M.H., Torabi S. Geochemistry of soil and human health: A Review. Pollution Res. 2009;28(2):257-62.

18. Page A, Miller R, Keeney D. Total carbon, organic carbon, and organic matter. Methods Soil Anal. 1982;2:539-79.

19. Hakanson L. An ecological risk index for aquatic pollution control.a sedimentological approach. Water Res. 1980;14(8):9751001.

20. Patel KS, Shrivas K, Hoffmann P, Jakubowski N. A survey of lead pollution in Chhattisgarh State, central India. Env Geochem Health. 2006;28(1-2):11-7.

21. Srinivasa Gowd S, Govil P. Distribution of heavy metals in surface water of Ranipet industrial area in Tamil Nadu, India. Env Monit Assess. 2008;136(1-3):197-207.

22. Siegel FR. Environmental Geochemistry of potentially Toxic Metals.; 2007.

23. Kumar S, Shirke KD, Pawar NJ. GIS-based colour composites and overlays to delineate heavy metal contamination zones in the shallow alluvial aquifers, Ankaleshwar industrial estate, south Gujarat, India. Env Geol. 2008;54(1):117-29.

24. Krishna AK, Govil PK. Heavy metal contamination of soil around Pali Industrial Area, Rajasthan, India. Env Geol. 2004;47(1):38-44.

25. Saeedi M, Li LY, Salmanzadeh M. Heavy metals and polycyclic aromatic hydrocarbons: Pollution and ecological risk assessment in street dust of Tehran.J Hazard Mater. 2012;15(227-8):9-17.

26. Mirzaei R, Ghorbani H, Hafezi Moghaddas N, Martín JAR. Ecological risk of heavy metal hotspots in topsoils in the Province of Golestan, Iran.J Geochem Explor. 2014;147, Part B:268-76. 